\title{
Dieter Weber. « Testing Food and Garment for the Ōstāndār: Two Unpublished Documents from the "Pahlavi Archive" in Berkeley, CA »
}

\section{Rika Gyselen}

\author{
(2) OpenEdition \\ Journals \\ Édition électronique \\ URL : http://journals.openedition.org/abstractairanica/42642 \\ DOI : $10.4000 /$ abstractairanica. 42642 \\ ISBN : 1961-960X \\ ISSN : 1961-960X \\ Éditeur : \\ CNRS (UMR 7528 Mondes iraniens et indiens), Éditions de l'IFRI
}

\section{Référence électronique}

Rika Gyselen, « Dieter Weber. « Testing Food and Garment for the Ōstāndār: Two Unpublished

Documents from the "Pahlavi Archive" in Berkeley, CA » », Abstracta Iranica [En ligne], Volume 37-38-39 |

2018, document 15, mis en ligne le 10 mars 2018, consulté le 28 septembre 2020. URL : http://

journals.openedition.org/abstractairanica/42642; DOI : https://doi.org/10.4000/abstractairanica. 42642

Ce document a été généré automatiquement le 28 septembre 2020.

Tous droits réservés 


\section{Dieter Weber. « Testing Food and Garment for the Ōstāndār: Two Unpublished Documents from the "Pahlavi Archive" in Berkeley, CA "}

Rika Gyselen

\section{RÉFÉRENCE}

Dieter Weber. « Testing Food and Garment for the Ōstāndār: Two Unpublished Documents from the "Pahlavi Archive" in Berkeley, CA, », Bulletin of the Asia Institute, 25 (2011), 2015, p. 19-37.

Publication des documents Berk. 77 et 149 de "l'Archive Pehlevie" qui mettent en lumière que les biens - vêtements, viande - destinés à la maisonnée de l'ōstāndār étaient examinés auparavant par plusieurs personnes.

\section{AUTEURS}

RIKA GYSELEN

CNRS, Mondes iranien et indien 